\title{
The Democratization of South Korea: What Role Does Economic Development Play?
}

\author{
CHALMERS JOHNSON
}

What is the relationship, if any, between the movement toward democracy in Korea and the high levels of economic development achieved there?* One obvious conclusion that arises from a consideration of the Korean case is that the relationship is not the one identified in the Western theory of "bourgeois" revolutions. It is questionable whether economic development in Korea has produced a genuine middle class and, even if it has, the Korean middle class does not have an interest in and demonstrably has not championed political democracy during the first five Korean republics. The Korean developmental state is not antagonistic to the interests of the entrepreneurial-managerial elite in Korea, and it is thus meaningless to speak of a private sector favoring democracy as a way of controlling the public sector. Korea's possessing class is not a ruling class in the Marxist sense; it is rather the collaborator of a military-bureaucratic elite in a joint project of nationalist development. This configuration of political econ omy is quite compatible with authoritarian government for extended periods of time.

But there is a relationship between economic development and the advent of democracy in the Korea of the 1980s. Economic development caused conditions that in social science theory are called societal disequlibrium. The demands for democracy of the 1980s constituted efforts to resynchronize the Korean value structure with its division of labor and to overcome the sense of injustice and unfairness that Koreans felt in the 1980s but not in the 1960s. ${ }^{1}$

Korea's strategy of economic development, modeled after that of Japan, resulted in a pattern of markedly unbalanced development: high levels of economic development, significant levels of social development, and low levels of political development. This imbalance is particularly serious in cases where the strategy has produced great success in terms of its original premises - such as the case of Korea.

An unintended consequence of the strategy is a loss of societal equilibrium, that is, a loss of coherence between a society's structure of values 
and its division of labor. Depending on the appropriateness or irrelevance of the policies advanced by the political elites to deal with the imbalance, a genuine revolutionary situation may be created. This is what happened in Korea as a result of Chun's policies of military repression and the 24th Olympiad. Nonetheless, the fact that the student revolutionaries succeeded in driving Chun from office and launching the sixth republic should not be thought of as an inevitable or determined outcome. Revolutionary situations are only that - opportunities for change. In real life, and contrary to Marx, the forces of reaction often win and the forces of progress often lose. Fortunately for Korea, the outcome of its revolutionary confrontation was the foundation of political democracy.

Does the degree of economic development achieved in Taiwan and South Korea explain the timing of their movements toward democracy? Do their high degrees of economic development offer propitious circumstances for the establishment of democracy? Despite the contrary cases of Japan, where democracy seems to recede as the nation gets richer, and India, the Philippines, Costa Rica, and Colombia, where economic prosperity has not accompanied democracy, many observers think there is a positive correlation between economic growth and democracy. John $\mathrm{T}$. Bennett, after some initial reluctance, accepts that "economic growth, at least that which is widely shared, promotes democracy"; and he quotes the Wall Street Journal in commenting on Korea's new democracy, "You can't sustain economic growth over the long run without relaxing political restrictions." ${ }^{2}$ These views reflect in part the Western theory that the emergence of a true bourgeoisie (literally "people of the cities", but in context meaning middle classes) provides the foundation and chief cause of political democracy. Barrington Moore is categorical on the subject: "We may simply register strong agreement with the Marxist thesis that a vigorous and independent class of town dwellers has been an indispensable element in the growth of parliamentary democracy. No bourgeoisie, no democracy." ${ }^{3}$ Thus, according to at least one version of common Western theory, economic growth in Taiwan and Korea has probably led to the emergence of a middle class in each country and that is why democracy is starting to appear there.

But there are problems with this theory, particularly as it relates to the most advanced capitalist countries, the United States and Japan. American democratic theory does not prescribe any particular level of economic development or the existence of a middle class for democracy to flourish. 
The Americans are, in fact, largely silent on the relationship, if any, between economics and democracy. This may, of course, merely reflect American myopia. Tocqueville thought that democracy succeeded in America for two reasons: the place was naturally rich, and the United States lacked a heritage of feudalism. The latter condition was important to help distinguish it from Latin America, which was equally rich but a failure at democracy. Reflecting on Tocqueville, Arthur Schlesinger came to this generalization: "Democracy is unlikely to last without economic progress, but economic progress does not guarantee democracy."

Japan appears to be an illustration of Schlesinger's point. Japan's attempts at democracy, as periodized by Rokuro Hidaka, break down into the following pattern of three attempts and three failures:

First phase: Meiji Restoration, 1868 to c. 1890. A period of "enlightenment", with movements towards liberty, people's rights, and democracy.

Second phase: 1890 to c. 1912. A period of nationalism and imperialism, in which democracy waned.

Third phase: 1912 to 1931. A period in which attempts were made to bring the absolutist system (tennosei) under democratic constraints, known as the era of Taisho Democracy.

Fourth phase: 1931 to 1945. A period of militarism, ultra-nationalism, and the suppression of all democratic tendencies.

Fifth phase: 1945 to 1960. A period of intense democratization in the wake of Japan's defeat and the reforms of the Allied occupation.

Sixth phase: 1960 to the present. A period of high-speed economic growth based in part on single-party government and the avoidance of political problems.

Throughout this 120-year period Japan continued to experience significant economic progress, but capitalism in the Japanese form does not produce or even seem to need political democracy in order to function. Contrary to Western bourgeois theory, capitalism in Japan seems to have flourished when democracy was weakest. Hidaka explains: "In the prewar period, the state unified the Japanese people by fostering loyalty to the Emperor. Today, the state coopts the people by elaborately redistributing profits to meet the people's expectations....The high-growth economy 
made this ability to redistribute profits possible... The postwar period can be divided into two phases: the phase of postwar democracy and the phase of high economic growth....The high-growth economy of Japan which began in the 1960s created a new state completely different in quality from the Japanese state during or immediately after the war." ${ }^{\prime \prime}$ In other words, the periods of greatest economic growth in Japan coincide with periods of growing authoritarianism, not with periods of democracy, as Western theory suggests.

If the link between economic growth and democracy is problematic, i.e., not obvious, and the evidence from the major East Asian cases (Japan, Korea, and Taiwan) ambiguous, then let me turn to a direct analysis of the relationship between economic growth and democracy. First, however, what do I mean by democracy? It is necessary to answer this question as specifically as possible because the concept of democracy is buried under so many layers of philosophy, description, and propaganda as to make it almost meaningless.

I follow Karl Popper's distillation of the essence of democracy for three reasons: (1) it is parsimonious; (2) it does not depend on a particular culture or religious heritage (e.g., a Periclean Age, Judeo-Christian ethics, or the Natural Law); and (3) it is very relevant to the transition from authoritarianism to democracy as it is encountered in East Asia today. Popper writes, "How is the state to be constituted so that bad rulers can be got rid of without bloodshed, without violence?...The modern so-called democracies are all good examples of practical solutions to this problem....]They all adopt[ the principle that the government can be dismissed by a majority vote.... Nowhere do the people actually rule. It is governments that rule, ]including[ our civil servants - or our uncivil masters, as Winston Churchill called them....]Democracy thus means[ not a theory of the 'rule of the people', but rather the rule of law that postulates the bloodless dismissal of the government by a majority vote."

Popper's principle can be stated positively. What democracy requires is the institutionalization of a competitive process by which people choose their leaders. Competition involves a rule-bound contest in which both sides recognize the legitimacy of the other side's interests and strategies so long as both sides obey the rules. Such institutions as the rule of law, bills of rights, constitutions, judicial review, and legislative oversight are devices to set, maintain, umpire, and when necessary change the rules of political competition. Democracy is the set of institutions that allows the 
citizens to hold their governments accountable for what they have done and what they propose to do. In a democracy, election day is judgment day. Democracy in this specific sense should be distinguished from two related concepts - namely, pluralism and liberalization. Pluralism refers to a state of complexity or diversity in a society that is commonly, but not exclusively, caused by processes of economic development (it may also be caused by immigration, acculturation, regionalism, and other non-economic forces). The advent of a pluralistic society often has the effect of increasing demands for democracy, since majoritarianism and the concensus building it entails coheres better with pluralism than any other form of government. Pluralism thus may be a cause of democracy, but not all democracies are necessarily pluralistic regimes (e.g., ancient Athens was not pluralistic in any contemporary sense of the term).

Liberalization refers not to pluralism or democratization but to the process of granting or establishing rights that protect individuals and social groups from arbitrary or illegal acts committed by the state or other citizens. Such rights include habeas corpus, security in one's home, protection of private property, guarantee of a fair trial, and freedom of movement, speech, and religion. These rights may come from tradition, the common law, a fundamental grant of liberties such as the Magna Carta (1215), struggles between the executive and legislative branches of government, developments in the criminal law, and so forth.

In very general terms, pluralism promotes demands for liberalization, and liberalization is conducive to democratization. The American revolution at the end of the eighteenth century, for example, was caused in part by a process of liberalization that had gone on for the previous two centuries. The purpose of the revolution was to establish democracy in order to secure preexisting liberal rights against encroachments by (in the eyes of the Americans) English tyrants. When democratization takes place before the development of either pluralism or liberalization, the resultant democracy may fail - as in China in 1912, or most Latin American countries during the nineteenth century, or in Korea in 1960-61. But, again, liberalization is not the same thing as democracy; one may cause the other and vice versa. Until very recently both Taiwan and South Korea have been more pluralistic and liberal than, for example, mainland China without being democracies.

Keeping these fundamental distinctions in mind, let me try to relate 
the occurrence of democracy to various economic influences. It is possible for democratizing movements to have no connection at all to the economy. A people may have ample reasons for wanting to judge and to be rid of its government other than for economic reasons: Manila, February 1986, offers a good example. But there are cases in which people strive for democracy precisely to check the economic power of the state and to advance their own economic interests instead. These are the classic cases of the West associated with the concept of "bourgeois revolution." In these cases the capitalists opposed the monopol or predominance of the state in economic affairs; and they were able to prevail against the state because they did not require state assistance in capital accumulation or in breaking up potentially socialist workers' movements and because the traditional landlord class had lost its potency. The industrial bourgeoisie of the West thus developed strong economic interests in restricting state power and in promoting a laissez faire (i.e. government free) economy. It sought and defended democracy as a way to achieve these ends and to prevent political power from being used against it by groups with different economic interests. In this way the concept of democracy came to be associated with the interests of the middle class, but it actually refers only to the development of democracy and capitalism in some countries of the West. To make a general principle out of the particular bourgeois-democratic relationship that developed in Europe in the nineteenth century is to overgeneralize the experience of the West - but that is what virtually all Western social science theory does.

The relationship between democracy and the economy obviously changes when the state leads economic development, when it directly mobilizes and allocates capital, when it licenses or subcontracts its projects to private entrepreneurs, and when it plays the predominant role in controlling the organization of workers. This is the pattern that prevails under the "capitalist developmental state" (CDS), a configuration which Japan invented and of which Korea since 1961 is a prime example. ${ }^{7}$ In these cases very high levels of economic development can be achieved without eliciting any so-called bourgeois pressure to liberalize or democratize, and a collaborative but illiberal relationship between the state and private capital can persist for long periods of time. In the CDS, the role of entrepreneurship is largely preempted by the state, and private capitalists in effect fulfill contracts authorized by the state. Even so, as the CDS progresses to advanced levels of capital-intensive and knowledge-inten- 
sive industrialization, the resulting high levels of pluralism will create a crisis of stability that can lead to democracy. There are various configurations that this crisis will take, and the process of resolving the crisis has as much to do with the occurrence of a democratic or a non-democratic outcome as the causes of pluralism itself. Before I turn to those configurations, however, let me briefly review the theory of intentional economic development in order to show the place of the CDS in it.

From a contemporary political economy perspective, the theory of intentional economic development is composed of four broad elements, the most important aspect of which is that they must occur in the following order: 1) a receptive social environment; 2 ) determined leadership; 3 ) technical competence; and 4) money (i.e. capital). The order is important; pouring aid money into places without either a receptive social environment or determined leadership or technical competence will not produce development but only corruption. Let me expand on each of these elements.

The idea of a receptive social environment is the broadest and least well formulated aspect of the theory. It is merely a catchall category to take into account the influence of cultural factors. The theory argues (or acknowledges) that intentional development cannot succeed in a culture that is hostile to economic activities or is so riven with ethnic, religious, caste, or tribal disputes as to put economic affairs on a low priority. Iran during and after 1979 offers an example of a culture that stood in the way of economic development, as does Spain during much of the nineteenth and twentieth centuries. Generally speaking, all of the countries of the Sinitic cultural area have societies that are conducive to development, although in several cases ideology and extreme forms of nationalism have been as severe obstacles to development (e.g., Vietnam, North Korea) as culture is elsewhere.

The second element of the theory, „determined leadership», means something very specific. It refers to a draconian process of priority setting and maintaining. The theory holds that the overall process of development must be disaggregated into economic development, social development, and political development, each of which can be understood in per capita terms. Economic development means per capita increases in productivity. Social development means per capita increases in such measures as life expectancy at birth, basic education, health care, access to media of communication, and leisure time. Political development means 
per capita increases in access to forums where binding decisions for the society as a whole are made. Political development is not synonymous with democratization - access and the ability of a majority to dismiss the government are not the same - but the existence of democracy is evidence of advanced levels of political development.

The role of leadership in a campaign of intentional development is to promote one aspect of development, usually economic development, at the expense of the other two. (One can imagine a situation in which first priority is given to either political or social development at the expense of the other two, but these cases are less common. Mao's policies during the Chinese Cultural Revolution are an example of political development being advanced at the expense of social and economic development). Giving priority to the economic sector requires that the leadership develop intrusive and preemptive capacities that can demobilize the social and political sectors while pouring resources into the economic sector. Based on the important historical cases (primarily Japan and the USSR), the theory holds that only unbalanced schemes of development can succeed. Attempts at balanced development will only frustrate all development as resources will be spread too thinly into welfare schemes of politically popular projects. Determined leadership presupposes the existence of a serious, ruthless, informed elite - a Meiji oligarchy, a communist party politburo, or a military junta such as that of Park Chung- Hee - that can force these priorities on the society. Needless to say, to the extent that the developmental elite succeeds in its task, it will produce a seriously unbalanced society, one that is highly developed economically, moderately developed socially, and deeply underdeveloped politically. It is this imbalance that produces the ultimate crisis of legitimacy for developmental elites.

The third element of the theory, technical competence, refers to the need to educate enough members of the society to be able to staff the factories, offices, and governmental bureaus of a modern economy. Determined leadership without technical competence is not enough; that is what mainland China has had since its First Five-Year Plan (1953-57). All of the East Asian CDSs are heavy investors in education. Of course, this commitment to education leads to a contradiction: the greater the degree of education the harder it is to keep the social and political sectors demobilized. A strong nationalistic content to the education and controls over private contacts with the external world can mitigate its effects, however. Both Japan and the USSR illustrate the point that the unbalanced configuration even 
with high levels of education can last longer than many Western critics of these systems believe.

The final element of the theory, money, means that even the society perfectly organized for development must still find, squeeze out, or borrow funds that it can invest in more productive facilities. The ultimate need of the developing society is capital, that is wealth in whatever form that is not consumed but used to produce more wealth. The normal sources of developmental capital are forced savings, borrowing, and international aid. Another duty of determined leadership is to force savings from the population by restricting its consumption.

Nation-states undertaking programs of intentional economic development usually do so for non-economic motives - national security, political ideology, overcoming neo-colonialism - and are therefore more concerned with the effectiveness of their programs than with their efficiency. This is one of the reasons that they usually do not pay much attention to the advice of professional economists. At some point, however, very inefficient schemes of state entrepreneurship become ineffective and must be reformed. Generally speaking, there are three broad patterns of state-initiated economic development -1) those in which the state monopolizes ownership and control of all productive assets, 2) those in which the state retains ownership but decentralizes control to the level of enterprises and households, and 3) those in which the state eschews ownership but exercises control through the manipulation of incentives, rationing of resources and capital, cartels, and so-called "administrative guidance". Examples of the first are the true "command economies" (e.g. the USSR), examples of the second are the reformed command economies (e.g. Hungary, mainland China), and examples of the third are the CDSs (e.g., Japan, South Korea, and Taiwan). Economies in which both ownership and control are in private hands and the state is restricted to a regulatory role approximate the laissez faire model of neo-classical economic theory (e.g., the United States, Hong Kong). It is also only the latter to which neo-classical economic theory is relevant. ${ }^{8}$ Of these four types the CDS is historically the most successful in terms of the levels and pace of economic development actually achieved. It is not without its human costs, but in general it is also less costly in human suffering than the Soviet-type command economy. ${ }^{9}$

A successful CDS, that is, one that has broken through to self-sustaining economic growth, sooner of later must face a crisis caused by its extreme imbalance. Japan during the 1920 s displayed this configuration in an acute 
form: high economic development, fair social development, and poor political development. During the decade Japanese elites undertook various reforms intended to correct the imbalance in the society, but these were eventually overwhelmed by an international crisis. There is nothing predetermined about the outcome of the crisis of imbalance: it may lead to renewed authoritarianism (as in Japan in the 1930s), it may lead to democratization (perhaps contemporary Spain and Portugal are examples), and it may lead to an indefinite postponement of any resolution so long as the elites are able to »manage the crisis (e.g. Russia under Brezhnev, Japan today). ${ }^{10}$

The breakdown of authoritarian regimes is contingent on a host of factors. One of the most important is leadership errors by the elite that make the crisis situation worse. This is the most common final cause of revolution. ${ }^{11}$ If, for example, the elite is constituted as an exclusive body, e.g., a military elite, it cannot use its greatest potential weapon in attempting to defuse the situation - namely cooption of protest leaders into the status quo elite. The Mexican ruling party has used this gambit for years, and the Kuomintang in Taiwan has largely defused the Taiwanese separatist issue by coopting Taiwanese into the party and the government. A regime that cannot coopt protesters is much more fragile than one that can. Some classic examples of leadership errors that deepened the crisis include Louis XVI's calling the estates general in 1789; Ferdinand Marcos calling a snap election in February 1986; and Chun Doo-Hwan's decision of April 13, 1987, to suspend further debate on the Korean Constitution.

The transition from authoritarian rule to more popular forms of government, when it occurs, usually occurs for one of three reasons. The first is international factors, commonly defeat in war. Japan owes its democracy today to its loss of a big war to the right people at the right time. Similarly, contemporary Argentine democracy came about because Argentina lost the Falklands War, thereby discrediting its military regime. The second reason is a decision unilaterally by the authoritarian regime to liberalize, which often leads to democratization. It may do so because it recognizes that the success of its economic development program has produced many medium and smaller enterprises that are beyond its control. Both because it trusts the moderation of these bourgeois forces and to avoid seeing them radicalized, the regime decides to liberalize. Something like this is occurring in Taiwan today. The third reason for the transition is the development of a true revolutionary situation. These cases will be resolved either 
through revolutionary violence or else one side or the other, usually the one with the least legitimacy, will back down and undertake reforms.

South Korea offers a vivid illustration of these generalizations about intentional economic development and the crisis of unbalanced development that it produces when it succeeds. Let me therefore try to place the Republic of Korea in the perspective outlined here. All CDSs are authoritarian (explicitly or covertly) but not all authoritarian regimes are CDSs. Some authoritarian regimes are merely preservative. ${ }^{12}$ South Korea has experienced both kinds: under the First Republic of Syngman Rhee (1948-60) and under the Third (1962-72) and Fourth Republics (1972-80) of Park Chung-Hee. The Masan Revolution of April 19, 1960, that overthrew Rhee was a straight-forward democratic revolution without economic causes. It has strong similarities to the Aquino Revolution of 1986 in the Philippines and illustrates again that a people may want democracy - the ability to dismiss their government bloodlessly - regardless of their economic interests. Nonetheless, the Korean revolution of 1960 was important for later events because of the dramaturgy and precedents it established: it was led by students, a major student martyr was created (in $1960 \mathrm{Kim}$ Chu-Yol was tortured to death by the police just as in 1987 Park Jong-Chul died under similar circumstances), and authoritarian arrogance inflamed nonparticipants and caused them to rally behind the students.

The 1960 revolution and the subsequent 1961 military coup d'etat led to the creation in South Korea of a true CDS. Between 1962 and 1987 the Korean economy grew at an average rate of 8.9 percent per year, and for the years 1986 and 1987 it grew at 12.6 percent and 12.3 percent respectively. These growth rates have political significance in that they show that Korea could afford to bring its CDS into greater balance even if that caused its growth rate to fall into the 6 to 8 percent range. This economic development had the effect of shifting the composition of the Korean labor force from 79 percent engaged in the primary sector in 1961 to 70 percent engaged in the secondary and tertiary sectors in 1988. Nontheless, this shift did not produce a large middle class independent of the state, as in Taiwan, because the Korean CDS followed the Japanese model closely in its reliance on large, state-supported conglomerates (zaibatsu in Japan, chaebol in Korea). Professor Kim Kyong-Dong notes the political consequences: "The entrepreneurial-managerial elite initially emerged in the early period of the new republic in close collaboration with the politicobureaucratic sector, and has maintained the relationship essentially the 
same way throughout....The role played by the entrepreneurialmanagerial sector as far as the process of political democratization is concerned has been at most passive, if not negative. By actively leading the way to economic growth, it has provided soil for rising aspirations among the people for greater amounts of democracy. Nontheless, this sector has not actively sought to persuade the governing politico-bureaucratic elite to pursue democratization programs." ${ }^{13}$ So much for the Western theory of a middle class vanguard leading the way to democracy.

One important difference between the Korean CDS and military regimes in South America is that General Park civilianized his junta and operated the CDS under a facade of democracy and constitutionalism. Park and his allies replaced their uniforms with civilian clothes, and they worked through political parties (the Democratic Republican Party and its contemporary successor, the Democratic Justice Party) to control the National assembly. Equally important, Korea's generals-turned-politicians placed their cadres in the party and the secret police, and they dominated the armed forces, not the other way around. In Latin America the survival of the government run by generals depended almost entirely om the support of fellow military officers. Park's civilian front allowed him to coopt many technical elites, including those educated abroad. When the crisis of imbalance came to Korea, it did not directly discredit the armed forces thereby allowing them to remain neutral.

The crisis in Korea was precipitated by the February 1985 elections for the National Assembly, in which the New Korea Democratic Party, led by Kim Young-Sam and Kim Dae-Jung, emerged as the largest and most articulate force in the legislature. And this election was in turn conditioned by the approach of the 24th Olympiad, scheduled for Seoul in 1988, which focused international attention on Korea's economic successes and its political shortcomings. Sensing that he could not reestablish the bases of legitimacy of the Park regime for his own government, President Chun tried to win popular endorsement through support of Korean nationalism. Clearly he could not take credit for economic development (Chun's coup of 1980 had, in fact, threatened it), and the alleged threat from the North was beginning to wear thin as an excuse for military rule in the South. Thus, Chun sponsored Korean nationalism in the form of the Asian Games of 1986 and the Seoul Olympics of 1988.

The Olympics proved to be a great constraint, opening a window of opportunity for protest. If the government had declared martial law to stop 
the protests, which began in 1985, the International Olympic Committee would have been forced to shift the games elsewhere. That would have humiliated the nation and discredited Chun. Thus the demonstrations went ahead in favor of a constitutional amendment authorizing the direct election of the president. The intent of this change was to prevent Chun and his colleagues from perpetuating their rule through a Japanese-style single-party regime. In order to stop the demonstrations, Chun in April 1986 unexpectedly made a concession and declared that he would support any constitutional change endorsed by the National Assembly, where his party had de facto control. Chun himself promised to leave office in February 1988 in any case.

This concession ended the demonstrations and led to protracted squabbling and ultimate deadlock among the various political parties and factions. Then Chun misread the public mood and made a fatal blunder. Hoping to reverse his earlier concession and using the Olympics and his own departure from office as excuses, on April 13, 1987, President Chun said that he had decided »to put constitutional change on hold. «A month later, on June 10, the national convention of the Democratic Justice Party nominated former general Roh Tae-Woo as its candidate to succeed Chun in an indirect election. The country erupted in violent street demonstrations. A revolutionary situation existed in the sense that the protesters sensed public support shifting to their side and the government dared not use its ultimate weapons of coercion, the armed forces, because that would also have scuttled the Olympics. On June 29 candidate Roh split with Chun, accepted the opposition's demands for constitutional reform and an end to police surveillance of opposition politicians, and promised investigations of long-standing grievances. It was a masterful political move. The subsequent presidential election of December 16, 1987, and the parliamentary elections of April 26, 1988, ended the authoritarian regime in Korea, ushered in the Sixth Republic, and inaugurated parliamentary democracy.

What are its chances of surviving? In a broad socioeconomic sense chances are good because the Korean CDS was badly imbalanced and its degree of development and the consequent pluralism of the society called for compensatory political development. But the relationship between economic and political development is in no sense deterministic. There are several contingent factors, some working for Korean democracy and some working against it. Among the negative factors one is that the vanguards 
in the street battles of June 1987 were composed almost entirely of students and not substantial elements of the middle class. Student nationalism in Korea goes back at least to the 1919 demonstrations against the Japanese occupation, and it is therefore autonomous from the changes wrought by Korea's economic development. Given enough time the student movement will probably break down from within, particularly as it comes more to be dominated by intransigent radicals (the Minmintu, Sanmintu, and Chamintu factions). There may not be enough time, however, given that politically and economically Korea cannot afford the luxury of ceaseless street battles. ${ }^{14}$

One possible solution would be an American military withdrawal from Korea, which would defuse the main nationalistic issue that the students are attempting to exploit (American pressure for Korean reciprocity in terms of market access, the belief that the U.S. tacitly supported the Chun regime, including its use of force at Kwangju in May 1980, and the feeling that the American presence blocks progress toward negotiations with the North and improved relations with the Communist nations). Korea no longer needs American ground forces based inside the country to guarantee its security, and the growth of the Korean economy has caused the military budget to drop from 6 percent to 5 percent of GNP even as it is being expanded. American withdrawal could save the United States as much as $\$ 23$ billion per annum, an important consideration given the American fiscal imbalances, and guarantees of air and naval protection from American forces in the area could be continued. Perhaps most seriously, a continued presence of American ground forces inside Korea could damage Korean democracy because it both fuels student nationalism and continues Korea's dependent position as an American protectorate. The case for American withdrawal is strong. ${ }^{15}$

Another negative factor in preserving Korean democracy is the apparent unwillingness of all parties in Korean politics to abide by the rules of democratic competition and to compromise their differences. Even though Roh Tae-Woo made the first compromise in his historic declaration of June 29, 1987, his subsequent cabinet appointments of December 19 and his forcing through a new election law at 2:10 AM March 18 revived fears among the public that the government hopes to rig democratic procedures. Equally seriously, the inability of the opposition to unite behind principles rather than personalities and the extreme regionalism displayed in the elections of April 26 suggests that democracy may only be a 
slogan among many opposition politicians. If the Korean National Assembly, much like the Japanese Diet, proves unable to supervise and hold accountable Korea's formidable bureaucracy, democracy may prove to be only formal and empty.

On the positive side, the election of April 26 advanced the chances of political stability because it brought all the major dissidents and critics of the government into t the National Assembly. If the government party had triumphed, this would have produced an explosive polarization in society between the ins and the outs. The election, together with the discrediting of ex-president Chun following the arrest in March 1988 of his brother on corruption charges, means that the National Assembly has become the locus of Korean politics. Behind the scenes manipulation has become less important than parliamentary politics. Parliament is the great school of democracy, and Korea now has a healthy one.

A final factor working in favor of Korean democratization is that the people took direct action in a revolutionary situation and forced political reform. It was not something bestowed by a foreign conqueror (as in Japan) or from above by a liberalizing but still dominant elite (as in Taiwan). A persistent source of weakness in Japanese democracy is the feeling that it lacks grass roots. This shows up in many different places in Japan. In Christena Turner's study of labor disputes, for example, one labor leader said to her that the problem with democracy in Japanese unions is the same as for democracy in Japan as a whole:

The Japanese people never fought for democracy. They have never had to insist on their rights to participation. It was handed to them by the Americans and now we are all trying to make it work. But unless you know how to insist, how to fight, on your own behalf it can't really work. ${ }^{16}$

The best thing going for democracy in Korea is that the people themselves were involved in its creation and have a stake in its survival.

Chalmers Johnson is Professor of Asian Studies in the Graduate School of International Relations and Pacific Studies, University of California, San Diego.

\section{NOTES}

* This article was published earlier in a different form as "South Korean
Democratization: The role of Economic Development," The Pacific Review, Vol. 2, No. 1 (1989), pp. 1-10. 
1 For the relevant theory, see Chalmers Johnson, Revolutionary Change (Stanford: Stanford University Press, 1982), chap. 5.

2 John T. Bennett, "Political and Economic Development in Korea," paper prepared for the Conference on Development and Democracy in East Asia: Taiwan, South Korea, and the Philippines, American Enterprise Institute (A.E.I)., Washington, D.C., May 18-19, 1988; Wall Street Journal, May 3, 1988.

3 Barrington Moore, Jr., Social Origins of Dictatorship and Democracy (Boston: Beacon Press, 1966), p. 418.

4 Arthur Schlesinger, Jr., "Democracy: The American Experience," in Kim Kihwan, ed., Progress in Democracy: The Pacific Basin Experience (Seoul: The Ilhae Institute, 1987), p. 13.

5 Rokuro Hidaka, "Personal Retrospective," in Gavan McCormack and Yoshio Sugimoto, eds., Democracy in Contemporary Japan (Armonk, New York: M. E. Sharpe, 1986), pp. 228-46.

6 "Popper on Democracy," The Economist, April 23, 1988, pp. 19-22.

7 See Chalmers Johnson, MITI and the Japanese Miracle (Stanford: Stanford University Press, 1982); and "Political Institutions and Economic Performance: The Government-Business Relationship in Japan, South Korea, and Taiwan," in Frederic C. Deyo, ed., The Political Economy of the New Asian Industrialism (Ithaca, New York: Cornell University Press, 1987), pp. 136-64. For a discussion of South Korea as a CDS, see Ahn Byung-Joon, "Korea's Political Economy and International Environment," paper prepared for the A.E.I. Conference.

$8 \mathrm{I}$ am indebted to Wu Yu-shan for these distinctions based on ownership and control. See his "Leninist State and Property Rights: Economic Reform in the People's Republic of China" (Ph.D. dissertation, political science, Univer- sity of California, Berkeley, forthcoming). On the relevance of neo-classical economic theory to the CDS, see Chalmers Johnson, "The Japanese Political Economy: A Crisis in Theory," Ethics and International Affairs, Vol. 2 (1988), pp. 79-97.

9 For a listing of some of the human costs of Japanese development, see Mikiso Hane, Peasants, Rebels, and Outcasts: The Underside of Modern Japan (New York: Pantheon, 1982).

10 Note that Professor Hidaka refers to Japan today as a kanri kokka, which he translates as "control state" but might more accurately be rendered "managerial state." Cf. McCormack and Sugimoto, Democracy in Contemporary Japan, p. 244.

11 See Plato, Republic, Book 8.; Cf. Johnson, Revolutionary Change, Chapter 5.

12 For further details, see Barry Rubin, Modem Dictators (New York: McGrawHill, 1987).

$13 \mathrm{Kim}$ Kyong-Dong, "Socio-Cultural Aspects of Political Democratization in Korea," paper prepared for the A.E.I. Conference, May 18-19, 1988. On the Korean conglomerates, see Fukagawa Yukiko, "Keizai o saseru zaibatsu pawä" (Zaibatsu Power that Maintains the Economy), Chīō kōron (March 1987), pp. 220-21. This is one of 13 articles in a special collection entitled "Nikkan shinteikei jidai no makuake" (Opening of a New Era of JapaneseKorean Cooperation), pp. 172-231.

14 On the Korean student movement, see Wonmo Dong, "Students and Politics in South Korea," Journal of International Affairs, Vol. 40, No. 2 (Winter-Spring 1987), pp. 235-55; and "Student Activism and the Presidential Politics of 1987 in South Korea," in Ilpyong Kim, ed., Political Change in South Korea (New York: Paragon House Press, 1988).

15 For the figure of $\$ 23$ billion, see "Cut South Korea's Umbilical Cord," New 
York Times, March 31, 1988. In a recent study of Korean-American relations, the Council on Foreign Relations opposes an American withdrawal, but it acknowledges that the relationship will worsen so long as the American presence continues. It also argues that the Koreans can avoid economic liberalization so long as the American protectorate is maintained since it also protects Korean vested interests from. change. Liberalization up to now has been only pro forma because of "the preference for government control of the economy on the part of bureaucrats and the businesses that benefit from it, the anti-import bias built into the system (import liberalization is carefully planned in consultation with the businesses that will be affected to minimize the impact), and the fear of political repercussions." See Korea at the Crossroads (New York: Council on Foreign Relations, 1987), p. 33.

16 Christena Turner, "The Phoenix Falters," paper presented at the Colloquium of the Center for Japanese Studies, University of California, Berkeley, April 20, 1988. 